1 Holen J, Aslid R, Landmark K, Simonsen S. Determination of pressure gradient in mitral stenosis with a noninvasive Doppler ultrasound technique. Acta Med Scand 1976;199:455-60.

2 Krafchek J, Robertson JH, Radford M, Adams D, Kisslo J. A reconsideration of Doppler assessed gradients in suspected aortic stenosis. Am Heart $f$ 1985;110:765-72

3 Yoganathan AP, Cape EG, Sung H-W, Williams FP, Jimoh A. Review of hydrodynamic principles for the cardiologist: applications to the study of

4 Clark C. The fluid mechanics of aortic stenosis: I Theory and steady flow experiments and II Unsteady flow experiments. $\mathcal{F}$ Biomechanics 1976; 9:521-8 and 567-73.

5 Baumgartner H, Khan S, DeRobertis M, Czer L, Maurer G. Discrepancies between Doppler and catheter gradients in aortic prosthetic valves in vitro: a manifestation of localized pressure gradients and pressure recovery. Circulation 1990;82:1467-75.

6 Levine RA, Jimoh A, Cape EG, McMillan S, Yoganathan AP, Weyman AE. Pressure recovery distal to a stenosis: potential cause of gradient "overestimation" by Doppler echocardiography. fACC 1989;13:706-15.

7 Holen J, Waag RC, Gramiak R. Doppler ultrasound in aortic stenosis: in vitro studies of pressure gradient determination. Ultrasound in Medicine $\mathcal{E}$ Biology 1987;13:321-8.
8 Tindale WB, Trowbridge EA. Evaluation in vitro of prosthetic heart valves: pulsatile flow through a compliant aorta. Life Support System 1983; 1:173-85.

9 Vasko SD, Goldberg SJ, Requarth JA, Allen HD. Factors affecting accuracy of in vitro valvular pressure gradient estimates by Doppler ultrasound. Am 7 Cardiol 1984;54:893-6.

10 Hegrenaes L, Hatle L. Aortic stenosis in adults. Non-invasive estimation of pressure differences by continuous wave Doppler echocardiography. $\mathrm{Br}$ Heart $\mathcal{f} 1985 ; 54: 396-404$.

11 Vandervoort PM, Greenberg NL, Pu M, Powell KA, Cosgrove DM, Thomas JD. Pressure recovery in bileaflet heart valve prostheses: localized high velocities and gradients in central and side orifices with implicaized high velocities and gradients in central and side orifices with implications for Doppler-catheter gra
Circulation 1995;92:3464-72.

12 Currie PJ, Seward JB, Reeder GS, Vlietstra RE, Bresnahan DR, Bresnahan $\mathrm{JF}$, et al. Continuous-wave Doppler echocardiographic assessment of severity of calcific aortic stenosis: a simultaneous Doppler-catheter correlative study in 100 adult patients. Circulation 1985;71:1162-9.

13 Fischer $\mathrm{L}$, Haberer $\mathrm{T}$, Dickson $\mathrm{D}$, Henselmann $\mathrm{L}$. Comparison of Doppler echocardiographic methods with heart catheterisation in assessing aortic valve area in 100 patients with aortic stenosis. Br Heart $f$ 1994;73: 293-8.

\title{
STAMPS IN CARDIOLOGY
}

\section{Sir Thomas Lewis (1881-1945)}

The only stamp depicting Sir Thomas Lewis was issued by Mauritius on the centenary of his birth. At five rupees it was the highest value stamp in a set featuring past eminent personalities, and the only one devoted to a non-Mauritian. The credit for it goes to the then Prime Minister of Mauritius, the late Dr Sir Seewoosagur Ramgoolam who had been a pupil of Lewis at University College Hospital London in the 1930s. The suggestion for the stamp came from Dr Arthur Hollman. The design shows the 1911 Cambridge string galvanometer electrocardiograph used by Lewis and his photograph at age 33 .

Thomas Lewis was born in Cardiff of Welsh parents. Having written his first scientific paper at the age of 19, he graduated in 1905 from University College Hospital London where he worked for the rest of his life. Einthoven's invention of the string galvanometer in 1901 made clinical electrocardiography a practical proposition and Lewis did more than anyone to establish its value. His 1911 book The Mechanism of the Heart Beat was hailed as the bible of electrocardiography, and his electrophysiological work gained him the FRS. He identified atrial fibrillation and proposed that its mechanism was a "circus movement". In 1909 he founded, with James Mackenzie, the influential journal Heart and was its only editor. Although he was a founder member of the Cardiac Club and wrote a widely acclaimed book, Diseases of the Heart,

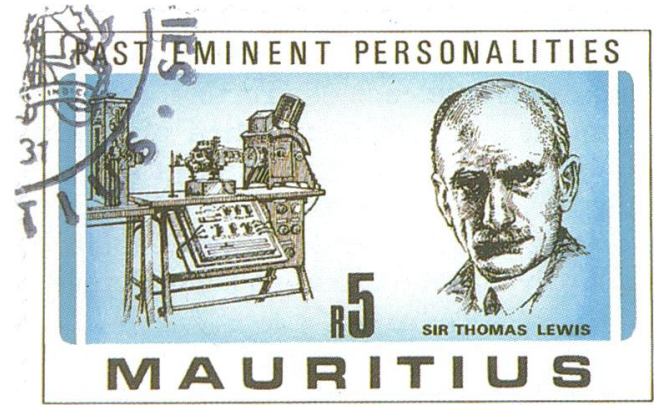

Lewis was more than a heart specialist (he disliked the term cardiologist). His guiding star was experimental medicine, and he eagerly promoted the discipline of clinical science and founded the Medical Research Society. He gave up electrocardiography in 1925 and then had two equally successful periods of research, firstly on the blood vessels of the skin and the triple response to injury, and secondly on pain. Lewis drove himself at high pressure and nothing was allowed to interfere with the work in hand. He was a tough chief, but his co-workers, many of them American, were inspired by his search for the truth and greatly admired him. Away from work his chief love, ever since boyhood, had been in natural history and he was a fine bird photographer and a skilful fisherman. He died after a third myocardial infarction, having had the first at the age of 43. 